\title{
Less Airway Inflammation and Goblet Cell Metaplasia in an IL-33-Induced Asthma Model of Leptin-Deficient Obese Mice
}

\section{Atsushi Kurokawa}

Tokyo Women's Medical University: Tokyo Joshi Ika Daigaku

Mitsuko Kondo ( $\boldsymbol{\nabla}$ kondo.mitsuko@twmu.ac.jp )

Tokyo Women's Medical University: Tokyo Joshi lka Daigaku https://orcid.org/0000-0003-3673-5431

\section{Ken Arimura}

Tokyo Women's Medical University: Tokyo Joshi Ika Daigaku

\section{Shigeru Ashino}

Tokyo Women's Medical University: Tokyo Joshi lka Daigaku

\section{Etsuko Tagaya}

Tokyo Women's Medical University: Tokyo Joshi lka Daigaku

\section{Research}

Keywords: asthma, obesity, eosinophils, goblet cell metaplasia, innate immunity

Posted Date: September 28th, 2020

DOl: https://doi.org/10.21203/rs.3.rs-82709/v1

License: (c) (i) This work is licensed under a Creative Commons Attribution 4.0 International License. Read Full License

Version of Record: A version of this preprint was published at Respiratory Research on June 1st, 2021. See the published version at https://doi.org/10.1186/s12931-021-01763-3. 
1 Less airway inflammation and goblet cell metaplasia in an IL-33-induced asthma model

2 of leptin-deficient obese mice

3

4 Atsushi Kurokawa' ${ }^{1)}$, Mitsuko Kondo ${ }^{1)}$, Ken Arimura ${ }^{1)}$, Shigeru Ashino ${ }^{2)}$, Etsuko

$5 \quad$ Tagaya $^{1)}$

6

7 1) Department of Respiratory Medicine, Tokyo Women's Medical University, Tokyo

8 162-8666, Japan.

9 2) Department of Microbiology and Immunology, Tokyo Women's Medical University,

10 Tokyo 162-8666, Japan.

11

12 Corresponding author

13 Mitsuko Kondo, M.D.

14 Department of Respiratory Medicine, Tokyo Women's Medical University, Tokyo 162-

15 8666, Japan.

16 E-mail: kondo.mitsuko@twmu.ac.jp

17 Tel: $81-3-3353-8111$

18 Fax: 81-3-5269-7616

19

20

21

22

23

24 
Abstract

26 Background: Asthma with obesity is a phenotype of severe asthma. Leptin exerts an

27 immunomodulatory effect and its level is increased in obesity. IL-33 is associated with

28 innate immunity and induces type 2 inflammation, and is present in adipose tissue.

29 However, the role of IL-33 and leptin in obesity-associated asthma is not fully

30 understood. We examined the effect of IL-33 on eosinophilic inflammation, goblet cell

31 metaplasia, and airway responsiveness in leptin-deficient obese (ob/ob) and wild-type

32 mice, and examined the effect of exogenous leptin pretreatment.

33 Methods: In ob/ob and wild-type mice, IL-33 was instilled intranasally on three

34 consecutive days. In part of the animals, leptin was injected intraperitoneally prior to

35 IL-33 treatment. The mice were challenged with methacholine and resistance of the

36 respiratory system (Rrs) was measured using the forced oscillation technique. Cell

37 differentiation, IL-5, IL-13, eotaxin, $\mathrm{KC}$ in bronchoalveolar lavage fluid (BALF), and

38 histology of the lung were analyzed. For the in vitro study, NCI-H292 cells were

39 stimulated with IL-33 in the presence or absence of leptin, and MUC5AC levels were

40 measured by ELISA.

41 Results: Ob/ob mice showed greater baseline Rrs than wild-type mice. IL-33 and IL-33

42 with leptin did not enhance Rrs challenged with methacholine compared to non-

43 treatment in ob/ob mice, whereas IL-33 with leptin enhanced Rrs in wild-type mice.

44 Ob/ob mice showed less IL-33-induced eosinophil numbers, IL-5, IL-13, eotaxin, and

$45 \mathrm{KC}$ levels in BALF and eosinophilic infiltration around bronchi and goblet cell

46 metaplasia than wild-type mice, but leptin pretreatment attenuated these changes in

47 ob/ob mice. MUC5AC levels were increased by co-stimulation with IL-33 and leptin in 48 vitro. 
49 Conclusions: Leptin plays an important role in IL-33-induced inflammation and goblet

50 cell metaplasia in the airway, but obesity per se increases airway hyperresponsiveness

51 independent of inflammation. These results explain some aspects of the pathogenesis of 52 obesity-related asthma.

53

54 Keywords: asthma, obesity, eosinophils, goblet cell metaplasia, innate immunity 55 
57 Background

58 The incidence of obesity is on the rise worldwide and is currently an important public

59 health problem. Obesity is a risk factor for the development of asthma and is associated

60 with poor control and frequent exacerbation [1]. Halder et al. previously reported that

61 obesity-related asthma shows the characteristic phenotype with female-dominant, late-

62 onset, non-eosinophilic, and highly symptomatic [2]. However, to date, there is no

63 specific treatment except for weight reduction in obesity-related asthma [3].

Leptin is a hormone secreted by adipocytes and acts on the hypothalamus to

65 inhibit hunger and stimulate satiety. In obesity, serum leptin levels are generally elevated

66 because leptin resistance occurs and a feeling of hunger continues despite high energy

67 stores [4]. However, the developmental mechanism of leptin resistance remains unclear

68 [5]. As leptin is known to exert an immunomodulatory effect, it may be involved in the

69 pathogenesis of obesity-related asthma. In obese women with asthma, airway reactivity

70 is significantly related to leptin expression in visceral fat [6]. Moreover, leptin and its

71 receptor are expressed in the airway epithelium [7].

72

Some studies have investigated the role of leptin in allergic animal models;

73 leptin enhanced airway responsiveness in ovalbumin (OVA)-sensitized mice [8].

74 Spontaneously generated leptin-deficient obese $(\mathrm{Ob} / \mathrm{ob})$ mice, show innate airway 75 hyperresponsiveness (AHR). Moreover, OVA-sensitized ob/ob mice show enhanced 76 AHR without an increase in type-2 inflammation [9]. However, these reports were 77 focused on adaptive immunity in the asthmatic response. On the other hand, the influence 78 of leptin on innate immunity has not yet been fully investigated. 

the airway. IL-33 is released from injured airway epithelial cells and stimulates type-2

81 innate lymphocytes (ILC2), which release IL-5 and IL-13. These cytokines lead to

82 eosinophilic inflammation, goblet cell metaplasia, and hyperresponsiveness in the 83 airway [10]. IL-33 and its receptor ST2 have also been shown to be present in human 84 adipose tissue [11]. However, the effect of obesity on IL-33-induced asthma, especially 85 the interaction between leptin and IL-33, is not fully understood. Herein we examined 86 the effect of IL-33 on eosinophilic inflammation, goblet cell metaplasia, and airway 87 responsiveness in ob/ob mice and leptin-treated wild-type C57BL/6J mice.

89 Methods

90 Animal models

91 This animal protocol was approved by the Animal Care and Use Committee of Tokyo 92 Women's Medical University (license numbers: AE20-065-B). Ob/ob mice (genetically 93 leptin-deficient obese mice, female, 7-9 weeks old) and C57BL/6J wild-type mice (age 94 and sex-matched with ob/ob mice) were divided into three groups (non-treated, IL-3395 treated, and Leptin + IL-33-treated). Recombinant mouse IL-33 (SRP3210, Sigma96 Aldrich, St Louis, MO, USA: $1 \mu \mathrm{g}$ dissolved in $50 \mu \mathrm{L}$ phosphate-buffered saline [PBS]) 97 was instilled intranasally on days 9-11, and recombinant murine leptin (450-31, 98 PeproTech, Cedarbrook Drive Cranbury, NJ, USA: $25 \mu \mathrm{g} / 125 \mu \mathrm{L}$ PBS for wild-type, 50 $99 \mu \mathrm{g} / 250 \mu \mathrm{L}$ PBS for ob/ob) was injected intraperitoneally on days $1,3,5$, and 8-11, as 100 the experimental protocol shown in Fig. 1a. 
103 Mice were anesthetized, ventilated (flexiVent; SCIREQ, Montreal, Canada), challenged

104 with increasing doses of inhaled methacholine $(3.125,6.25,12.5,25$, and $50 \mathrm{mg} / \mathrm{mL}$,

105 purchased from Sigma-Aldrich, St Louis, MO, USA), and the resistance of the

106 respiratory system (Rrs) was measured by the forced oscillation technique as previously

107 described [12]. Airway responsiveness was assessed by a fold change from baseline Rrs.

108

109 Bronchoalveolar lavage fluid (BALF) analysis

110 After measuring airway responsiveness, the BALF was collected by lavaging the lungs

111 with $1.8 \mathrm{~mL}$ PBS. The BALF was centrifuged at $500 \times g$ for $3 \mathrm{~min}$, and the supernatant

112 was collected for subsequent analysis. Total cell number was counted using a

113 hemocytometer, and the cell differentials were counted by staining with May-Giemsa.

114 Cytokine or chemokine levels (IL-5, IL-13, eotaxin, KC) were analyzed using a mouse

115 ELISA kit (R\&D system, Minneapolis, MN, USA).

116

117 Lung histology

118 The lungs were fixed with $10 \%$ formalin and embedded in paraffin. Sections were cut 5

$119 \mu \mathrm{m}$ thick and stained with periodic acid-Schiff/Alcian-blue. To assess goblet cell

120 metaplasia in the bronchi, mucus scores were obtained as previously described [13]. In

121 brief, bronchi with internal diameter measuring $>200 \mu \mathrm{m}$ in cross section is assessed.

122 Scores were obtained based on the ratio of goblet cell area to whole cross-sectional

123 epithelial area in each round bronchus: a score of 0 indicates none, a score of 1 indicates

124 occupation of $<1 / 3$ of the epithelial area, a score of 2 indicates occupation of $\geq 1 / 3$ to $<$

$1252 / 3$ of the epithelial area; and a score of 3 indicates occupation of $\geq 2 / 3$ of the epithelial

126 area. The mucus score was obtained by averaging the scores of the measured bronchi. 
128 In vitro study using NCI-H292 cells

129 For the in vitro study of mucin synthesis, the human pulmonary mucoepidermoid

130 carcinoma cell line NCI-H292 cells were cultured in RPMI 1640 medium (GIBCO;

131 Invitrogen Co. Grand Island, NY, USA) with 10\% fetal calf serum, penicillin (100

$132 \mathrm{U} / \mathrm{mL})$, streptomycin $(100 \mu \mathrm{g} / \mathrm{mL})$, and fungizone $(2.5 \mu \mathrm{g} / \mathrm{mL})$ at $37{ }^{\circ} \mathrm{C}$ in a humidified

$1335 \% \mathrm{CO} 2$ incubator. Cells were stimulated with IL-33 $(0.5 \mathrm{ng} / \mathrm{mL})$ in the presence or

134 absence of leptin ( $1 \mathrm{ng} / \mathrm{mL}) .24 \mathrm{~h}$ after stimulation, mucin-5AC (MUC5AC) protein

135 levels in cell lysates were measured with an ELISA kit (Cloud-Clone Corp, TX, USA)

136 as previously described [14]. The data are shown as percentages in non-stimulated

137 control cells.

138

139 Statistical analysis

140 All data are expressed as mean \pm standard error of the mean (SEM). Statistical

141 analyses were performed using the Prism 8 software package (GraphPad Software, San

142 Diego, CA, USA). Airway responsiveness was evaluated using two-way repeated

143 ANOVA with Turkey's post hoc test. All other data were evaluated using one-way

144 ANOVA with Turkey's post hoc test. A p-value of less than 0.05 was considered

145 statistically significant. In preliminary experiments, as we confirmed that leptin i.p.

146 alone did not affect airway hyperresponsiveness, BALF, or histology, we did not include 147 the data analysis.

148 
149

150

151

152 Body weight did not significantly change during the experiment in all mice, and ob/ob

153 mice were significantly heavier than wild-type mice (ob/ob $38.73 \pm 2.55 \mathrm{~g}$, wild-type

$15418.67 \pm 1.02 \mathrm{~g} ; \mathrm{p}<0.001$, on day 12) (Fig. 1b). Ob/ob mice showed significantly

155

156

157

158

159

160

161

162

163

164

165

166

167

168

169

170

171

Results

Leptin-deficiency was associated with less IL-33-induced eosinophilia and goblet cell metaplasia in ob/ob mice
$18.67 \pm 1.02 \mathrm{~g}, \mathrm{p}<0.001$, on day 12 ) (Fig. 1b). Ob/ob mice showed significantly

greater baseline Rrs than wild-type mice $(1.264 \pm 0.107$ vs. $0.721 \pm 0.023$

$\mathrm{cmH}_{2} \mathrm{O} . \mathrm{s} / \mathrm{mL} ; \mathrm{p}<0.01$ ) (Fig. 2a) and showed greater response to methacholine than

wild-type mice (Fig. 2b). However, in ob/ob mice, IL-33 with or without leptin induced no significant change in airway responsiveness (Fig. 2d). The total cell counts in BALF were lower in IL-33-treated ob/ob mice than in IL-33-treated wild-type mice (1.63 \pm 0.33 vs. $4.36 \pm 1.49 \times 10^{4}$ per $\mathrm{mL}$ ) (Fig. 3a). In wild-type mice, IL-33 induced marked eosinophilia in BALF (non-treated vs. IL-33-treated: 0.0 vs. $34.4 \pm 10.8 \%$; $p<0.05$ ).

However, in ob/ob mice, IL-33 did not induce significant eosinophilia (non-treated vs. IL-33-treated: 0.0 vs. $2.1 \pm 1.4 \%$ ). In ob/ob mice, leptin treatment prior to IL-33 instillation induced a significant increase in eosinophils (IL-33-treated vs. Leptin + IL33-treated: $2.1 \pm 1.4$ vs. $11.8 \pm 4.1 \% ; \mathrm{p}<0.05$ ) (Fig. $3 \mathrm{c}$ ), and also induced a significant increase in neutrophils $(0.8 \pm 0.4$ vs. $6.8 \pm 2.8 \%$; $<<0.05)$ (Fig. 3d). IL-5 and IL-13 levels in BALF were significantly lower in IL-33-treated ob/ob mice than in IL-33treated wild-type mice (IL-5: $4.5 \pm 2.4$ vs. $46.6 \pm 8.6 \mathrm{pg} / \mathrm{mL} ; \mathrm{p}<0.001, \mathrm{IL}-13: 1.1 \pm$ 0.9 vs. $13.9 \pm 5.5 \mathrm{pg} / \mathrm{mL} ; \mathrm{p}<0.05)($ Fig. $4 \mathrm{a}, 4 \mathrm{~b})$. Eotaxin levels tended to be lower in IL-33-treated ob/ob mice than in IL-33-treated wild-type mice (10.3 \pm 0.5 vs. $61.5 \pm$ $38.2 \mathrm{pg} / \mathrm{mL}$ ) (Fig. 4c). KC level was significantly lower in IL-33-treated ob/ob mice 
172 than in IL-33-treated wild-type mice $(8.9 \pm 2.3$ vs. $44.1 \pm 2.1 \mathrm{pg} / \mathrm{mL} ; \mathrm{p}<0.05)($ Fig.

$1734 d$ ). In ob/ob mice, leptin treatment increased IL-5, IL-13, eotaxin, and KC levels (IL-

174 33-treated vs. Leptin + IL-33-treated; IL-5: $4.5 \pm 2.4$ vs. $6.9 \pm 4.2$ pg/mL, IL-13: $1.1 \pm$ 1750.9 vs. $4.6 \pm 0.6 \mathrm{pg} / \mathrm{mL}$, eotaxin: $10.3 \pm 0.5$ vs. $69.7 \pm 57.7 \mathrm{pg} / \mathrm{mL}, \mathrm{KC}: 8.9 \pm 2.3$ vs.

$17631.7 \pm 11.1 \mathrm{pg} / \mathrm{mL}$ ), but these changes were not significant (Fig. 4a-4d). In non-treated

177 wild-type and ob/ob mice, neither airway inflammation nor goblet cell metaplasia were

178 observed (Fig. 5a, 5d). In IL-33-treated wild-type mice, airway inflammation and goblet 179 cell metaplasia were observed (Fig. 5b). On the other hand, in IL-33-treated ob/ob mice,

180 the changes were attenuated (Fig. 5e). However, addition of exogenous leptin induced

181 inflammation and goblet cell metaplasia (Fig. 5f). The mucus score was lower in IL-33182 treated ob/ob mice than in IL-33-treated wild-type mice $(0.33 \pm 0.07$ vs. $1.00 \pm 0.12, p$

$183<0.01$ ), but the addition of exogenous leptin significantly increased the mucus score in 184 ob/ob mice (IL-33-treated vs. Leptin + IL-33-treated; $0.33 \pm 0.07$ vs. $1.02 \pm 0.29 ; \mathrm{p}<$ $1850.05)$ (Fig. 5g).

186

187 Co-stimulation with leptin and IL-33 induced AHR in wild-type mice

188 In wild-type mice, airway hyperresponsiveness was induced by leptin + IL-33, but not 189 by IL-33 alone (Fig. 2c). In wild-type mice, leptin + IL-33 tended to increase 190 eosinophils and neutrophils in BALF compared to IL-33 alone, but these changes were 191 not significant (IL-33-treated vs. Leptin + IL-33-treated; eosinophil: $34.4 \pm 10.8 \%$ vs.

$19243.9 \pm 3.3 \%$, neutrophil: $3.7 \pm 1.4 \%$ vs. $14.4 \pm 6.1 \%$ ) (Fig. 3 c, 3 d). Leptin + IL-33

193 treatment significantly increased eotaxin and KC levels compared to IL-33 alone (IL-

194 33-treated vs. Leptin + IL-33-treated; eotaxin: $61.5 \pm 38.2$ vs. $209.9 \pm 13.9$ pg/mL; $\mathrm{p}<$ 


\section{In vitro study using NCI-H292 cells}

200 MUC5AC levels did not change with leptin and IL-33 alone, but were increased by co-

201 stimulation with leptin and IL-33 in vitro (leptin vs. leptin + IL-33; $100.6 \pm 2.6$ vs.

$202118.9 \pm 3.6 \% ; p<0.01$, IL-33 vs. leptin + IL-33; $105.6 \pm 3.0$ vs. $118.9 \pm 3.6 \% ; p<$ 203 0.05) (Fig. 6).

204

\section{Discussion}

206 In this study, ob/ob mice showed less eosinophilic inflammation and goblet cell

207 metaplasia induced by IL-33 compared to wild-type mice, but these changes were 208 attenuated by the exogenous administration of leptin. Furthermore, AHR was spontaneously elevated in ob/ob mice regardless of IL-33 treatment. These findings

210 suggest that leptin enhances IL-33-induced eosinophilic inflammation and goblet cell

211 metaplasia in the airway, and that obesity per se is associated with AHR, independent of 212 inflammation.

We demonstrated that IL-33-induced airway eosinophilic inflammation was

214 attenuated in ob/ob mice (Fig. 3c). In addition, IL-5, IL-13, eotaxin, and KC levels in 215 BALF were lower in IL-33-treated ob/ob mice than in IL-33-treated wild-type mice (Fig. $2164 a-4 d)$. Furthermore, the exogenous administration of leptin in ob/ob mice attenuated 217 these changes. Classically, it is known that OVA-sensitized ob/ob mice do not show an 
218 increase in type-2 inflammation [9]. Given that IL-33 induces type-2 cytokines from 219 ILC2, the attenuated eosinophilia in ob/ob mice may have been associated with the 220 decrease in IL-5, IL-13, and eotaxin. Zheng et al. demonstrated that leptin promotes the 221 proliferation of Th2 cells and ILC2s. They also demonstrated that leptin-deficiency leads 222 to reduced ILC2s and attenuated type-2 cytokine production [15]. Ding et al. reported that 223 ILC2 decreases in the adipose tissue of ob/ob mice [16]. Therefore, our results may have 224 been caused by a decrease in ILC2 in ob/ob mice. In wild-type mice, IL-33 induced goblet cell metaplasia (Fig. 5b) and increased 226 mucus score (Fig. 5g). Conversely, in ob/ob mice, IL-33-induced goblet cell metaplasia 227 was attenuated, and exogenous leptin administration reversed this change (Fig. 5e, 5f). 228 This may have been caused by the decrease in IL-13 in IL-33-treated ob/ob mice because IL-13 plays an important role in the induction of goblet cell metaplasia [17]. Furthermore, 230 in our in vitro study, MUC5AC levels were increased by co-stimulation with IL-33 and 231 leptin (Fig. 6). Leptin and its receptor are expressed in the airway epithelium [7]. The 232 asthmatic airway epithelium shows an increase in IL-33 expression [18]. Leptin is 233 reported to have the potency to induce mucin protein expression in human airway 234 epithelial cells [19]. Therefore, our in vitro study supports the hypothesis that leptin 235 deficiency disturbs mucin production in the IL-33-stimulated airway epithelium in ob/ob 236 mice. 238 wild-type mice in the absence of IL-33 (Fig. 2b). Ob/ob mice have innate AHR, which 239 might be induced by mechanical factors (low functional residual capacity or tidal 240 volume) and systemic inflammation caused by obesity or weight gain [20]. In our study, 241 exogenous leptin induced no significant change in AHR in IL-33-treated ob/ob mice 
242 (Fig. 2d), although airway inflammation and mucus secretion were augmented. One

243 possible explanation may be that the dose of exogenous leptin was insufficient to

244 enhance AHR. Conversely, leptin administration prior to IL-33 enhanced AHR in wild-

245 type mice (Fig. 2c). The addition of leptin to IL-33 induced a significant increase in

246 BALF eotaxin and KC in wild-type mice (Fig. 4c, 4d). It is suggested that augmented

247 airway inflammation plays a role in increased AHR in wild-type mice. Others also

248 reported that the addition of the OVA challenge [21] or IL-17A [22] to IL-33 enhanced

249 AHR compared to IL-33 alone.

250 We used female mice in this study. Obesity-related asthma is known to be

251 more prevalent in females than in males. Sood et al. reported that the association

252 between leptin and asthma appeared stronger in women than in men [23]. Visceral fat

253 leptin expression is significantly related to AHR in women with asthma [6]. It is well

254 known that obese women show severe airflow limitation, little eosinophilic

255 inflammation, and steroid unresponsiveness [24, 25]. Uddén et al. showed that

256 corticosteroids induce elevated serum leptin levels in women [26]. Increased body

257 weight and leptin levels induce much more AHR and worsening symptoms, especially

258 in women.

Based on the results of this experiment, we hypothesized that the mechanism

260 of obesity-related severe asthma is as follows. Increased body weight induces AHR due

261 to its mechanical factor, and elevated leptin combined with IL-33 induces airway

262 inflammation, goblet cell metaplasia, and more enhanced AHR. These two factors

263 (airway inflammation and AHR) could be associated with severe asthma. However,

264 human obesity shows increased leptin levels that differ from ob/ob mice. Even short- 
266 further studies are needed to clarify leptin- and obesity-related asthma in high-fat-diet-

267 induced animal models.

268

269 Conclusions

270 In summary, we showed that leptin combined with IL-33 plays an important role in

271 airway inflammation and goblet cell metaplasia, and that obesity per se increases AHR

272 independent of inflammation.

273

274 Availability of data and materials

275 The datasets used and/or analyzed during the current study are available from the

276 corresponding author upon reasonable request.

277

278 List of abbreviations

279 AHR: airway hyperresponsiveness

280 BALF: bronchoalveolar lavage fluid

281 ILC2: type-2 innate lymphocytes

282 Rrs: resistance of the respiratory system

284 Declarations

285 Acknowledgements

286 The authors have no conflicts of interest to declare. The authors thank Masayuki Shino

287 and Yoshimi Sugimura (Tokyo Women's Medical University) for their technical support. 
288 This study was supported in part by the Institute of Laboratory Animals (ILA) and 289 Medical Research Institute (MRI), Tokyo Women’s Medical University.

290

$291 \quad$ Funding

292 This study was partly supported by Grant 2016 from Novartis Pharmaceuticals Japan, 293 Grant 2017 from Merck \& Co. Inc., and Grant 2019 from Sanofi Japan.

294

295 Authors' Contributions

296 AK, MK, and KA designed the study and wrote the manuscript. SA and ET interpreted 297 the results. All authors have read and approved the final manuscript.

298

299 Ethics approval and consent to participate

300 This animal protocol was approved by the Animal Care and Use Committee of Tokyo

301 Women's Medical University (license numbers: AE20-065-B).

302

303 Consent for publication

304 Not applicable.

305

306 Competing interests

307 The authors declare that they have no competing interests.

308

309 
$311 \quad$ References

3121 Dixon AE, Holguin F, Sood A, Salome CM, Pratley RE, Beuther DA, Celedón JC,

313 Shore SA: An official American Thoracic Society Workshop report: obesity and asthma.

314 Proc Am Thorac Soc 2010, 7:325-335.

3152 Haldar P, Pavord ID, Shaw DE, Berry MA, Thomas M, Brightling CE, Wardlaw AJ,

316 Green RH: Cluster analysis and clinical asthma phenotypes. Am J Respir Crit Care Med $317 \quad 2008,178: 218-224$.

3183 Stenius-Aarniala B, Poussa T, Kvarnström J, Grönlund EL, Ylikahri M, Mustajoki P:

319 Immediate and long term effects of weight reduction in obese people with asthma:

320 randomised controlled study. BMJ 2000, 320:827-832.

3214 Friedman JM, Halaas JL: Leptin and the regulation of body weight in mammals.

322 Nature 1998, 395:763-770.

3235 Gruzdeva O, Borodkina D, Uchasova E, Dyleva Y, Barbarash O: Leptin resistance:

324 underlying mechanisms and diagnosis. Diabetes Metab Syndr Obes 2019, 12:191-198.

3256 Sideleva O, Suratt BT, Black KE, Tharp WG, Pratley RE, Forgione P, Dienz O, Irvin

326 CG, Dixon AE: Obesity and asthma: an inflammatory disease of adipose tissue not the 327 airway. Am J Respir Crit Care Med 2012, 186:598-605.

3287 Bruno A, Pace E, Chanez P, Gras D, Vachier I, Chiappara G, La Guardia M, Gerbino

329 S, Profita M, Gjomarkaj M: Leptin and leptin receptor expression in asthma. J Allergy

330 Clin Immunol 2009, 124:230-237, 237.e231-234.

3318 Shore SA, Schwartzman IN, Mellema MS, Flynt L, Imrich A, Johnston RA: Effect of 332 leptin on allergic airway responses in mice. J Allergy Clin Immunol 2005, 115:103-109. 
3339 Johnston RA, Zhu M, Rivera-Sanchez YM, Lu FL, Theman TA, Flynt L, Shore SA:

334 Allergic airway responses in obese mice. Am J Respir Crit Care Med 2007, 176:650335658.

33610 Schmitz J, Owyang A, Oldham E, Song Y, Murphy E, McClanahan TK, Zurawski G, 337 Moshrefi M, Qin J, Li X, et al: IL-33, an interleukin-1-like cytokine that signals via the 338 IL-1 receptor-related protein ST2 and induces T helper type 2-associated cytokines. 339 Immunity 2005, 23:479-490.

34011 Wood IS, Wang B, Trayhurn P: IL-33, a recently identified interleukin-1 gene family 341 member, is expressed in human adipocytes. Biochem Biophys Res Commun 2009, $342 \quad 384: 105-109$.

34312 Taniguchi A, Miyahara N, Waseda K, Kurimoto E, Fujii U, Tanimoto Y, Kataoka M, 344 Yamamoto Y, Gelfand EW, Yamamoto H, et al: Contrasting roles for the receptor for 345 advanced glycation end-products on structural cells in allergic airway inflammation vs. 346 airway hyperresponsiveness. Am J Physiol Lung Cell Mol Physiol 2015, 309:L789-800. 34713 Arai N, Kondo M, Izumo T, Tamaoki J, Nagai A: Inhibition of neutrophil elastase348 induced goblet cell metaplasia by tiotropium in mice. Eur Respir J 2010, 35:1164-1171.

34914 Takeyama K, Dabbagh K, Lee HM, Agustí C, Lausier JA, Ueki IF, Grattan KM, 350 Nadel JA: Epidermal growth factor system regulates mucin production in airways. Proc $351 \quad$ Natl Acad Sci U S A 1999, 96:3081-3086.

35215 Zheng H, Zhang X, Castillo EF, Luo Y, Liu M, Yang XO: Leptin Enhances TH2 and 353 ILC2 Responses in Allergic Airway Disease. J Biol Chem 2016, 291:22043-22052.

35416 Ding X, Luo Y, Zhang X, Zheng H, Yang X, Liu M: IL-33-driven ILC2/eosinophil 355 axis in fat is induced by sympathetic tone and suppressed by obesity. J Endocrinol 2016, 
35717 Kondo M, Tamaoki J, Takeyama K, Nakata J, Nagai A: Interleukin-13 induces goblet 358 cell differentiation in primary cell culture from Guinea pig tracheal epithelium. Am J 359 Respir Cell Mol Biol 2002, 27:536-541.

36018 Préfontaine D, Nadigel J, Chouiali F, Audusseau S, Semlali A, Chakir J, Martin JG, 361 Hamid Q: Increased IL-33 expression by epithelial cells in bronchial asthma. J Allergy 362 Clin Immunol 2010, 125:752-754.

36319 Woo HJ, Yoo WJ, Bae CH, Song SY, Kim YW, Park SY, Kim YD: Leptin up-regulates 364 MUC5B expression in human airway epithelial cells via mitogen-activated protein kinase 365 pathway. Exp Lung Res 2010, 36:262-269.

36620 Shore SA: Obesity and asthma: possible mechanisms. J Allergy Clin Immunol 2008, 367 121:1087-1093; quiz 1094-1085.

36821 Sjöberg LC, Nilsson AZ, Lei Y, Gregory JA, Adner M, Nilsson GP: Interleukin 33 369 exacerbates antigen driven airway hyperresponsiveness, inflammation and remodeling in 370 a mouse model of asthma. Sci Rep 2017, 7:4219.

37122 Mizutani N, Nabe T, Yoshino S: IL-17A promotes the exacerbation of IL-33-induced 372 airway hyperresponsiveness by enhancing neutrophilic inflammation via CXCR2 373 signaling in mice. J Immunol 2014, 192:1372-1384.

37423 Sood A, Ford ES, Camargo CA: Association between leptin and asthma in adults. 375 Thorax 2006, 61:300-305.

37624 Moore WC, Meyers DA, Wenzel SE, Teague WG, Li H, Li X, D'Agostino R, Castro 377 M, Curran-Everett D, Fitzpatrick AM, et al: Identification of asthma phenotypes using 378 cluster analysis in the Severe Asthma Research Program. Am J Respir Crit Care Med $379 \quad 2010,181: 315-323$. 
$38025 \mathrm{Wu}$ W, Bang S, Bleecker ER, Castro M, Denlinger L, Erzurum SC, Fahy JV, 381 Fitzpatrick AM, Gaston BM, Hastie AT, et al: Multiview Cluster Analysis Identifies 382 Variable Corticosteroid Response Phenotypes in Severe Asthma. Am J Respir Crit Care 383 Med 2019, 199:1358-1367.

38426 Uddén J, Björntorp P, Arner P, Barkeling B, Meurling L, Rössner S: Effects of 385 glucocorticoids on leptin levels and eating behaviour in women. J Intern Med 2003, $386 \quad 253: 225-231$.

38727 Fricke K, Vieira M, Younas H, Shin MK, Bevans-Fonti S, Berger S, Lee R, D'Alessio 388 FR, Zhong Q, Nelson A, et al: High fat diet induces airway hyperresponsiveness in mice. 389 Sci Rep 2018, 8:6404.

390 
$392 \quad$ Figure legends

393 Figure 1. (a) Experimental protocol. In leptin-treated groups, leptin $(25 \mu \mathrm{g} / 125 \mu \mathrm{L}$ 394 phosphate-buffered saline (PBS) for wild-type, $50 \mu \mathrm{g} / 250 \mu \mathrm{L}$ PBS for ob/ob) were 395 injected intraperitoneally on days 1, 3, 5, and 8-11. In IL-33-treated groups, IL-33 (1 $396 \mu \mathrm{g} / 50 \mu \mathrm{L}$ PBS) was instilled intranasally on days 9-11. On day 12 , airway 397 responsiveness, BALF, and lung sections were assessed. (b) Body weight. Data are 398 expressed as mean \pm standard error of the mean (SEM). $n=4-6$ for each group. $\# \# \#$ p $<$ 0.001 vs. mice with an identical treatment.

400

401 Figure 2. Airway responsiveness to methacholine. (a) Baseline resistance of the 402 respiratory system (Rrs) in wild-type and ob/ob mice. Airway responsiveness in (b) 403 non-treated wild-type and ob/ob mice, (c) non-treated, IL-33-treated, Leptin + IL-33404 treated wild-type mice, and (d) non-treated, IL-33-treated, Leptin + IL-33-treated ob/ob 405 mice. Data are expressed as mean \pm standard error of the mean (SEM). $n=4-5$ for each group. (a) ** $\mathrm{p}<0.01$, (b-d) Rrs is shown as fold change from baseline. Closed circle: 407 non-treated wild-type mice. Open circle: non-treated ob/ob mice. Closed square: IL-33408 treated wild-type mice. Open square: IL-33-treated ob/ob mice. Closed triangle: Leptin 409 + IL-33-treated wild-type mice. Open triangle: Leptin + IL-33-treated ob/ob mice. * p < $0.05, * * \mathrm{p}<0.01$ vs. non-treated wild-type mice.

412 Figure 3. The cell differentials of bronchoalveolar lavage fluid. (a) Total cells, (b) \% 413 macrophages, (c) \% eosinophils, (d) \% neutrophils, and (e) \% lymphocytes. Data are 
414 expressed as mean \pm standard error of the mean (SEM). $n=6-9$ for each group. ${ }^{*} \mathrm{p}<$ $0.05, * * \mathrm{p}<0.01, * * * \mathrm{p}<0.001$ vs. genotype-matched mice. $\# \mathrm{p}<0.05$, \#\# $\mathrm{p}<0.01$, \#\#\#

416 vs. $\mathrm{p}<0.001$ vs. mice with an identical treatment.

417

418 Figure 4. The cytokine and chemokine analysis in bronchoalveolar lavage fluid. (a) IL-

419 5, (b) IL-13, (c) Eotaxin, (d) KC. Data are expressed as mean \pm standard error of the 420 mean (SEM). $\mathrm{n}=6-9$ for each group. $* \mathrm{p}<0.05,{ }^{* *} \mathrm{p}<0.01, * * * \mathrm{p}<0.001$ vs.

421 genotype-matched mice. $\# \mathrm{p}<0.05$, \# $\mathrm{p}<0.01$, \#\#\# vs. $\mathrm{p}<0.001$ vs. mice with an 422 identical treatment.

423

424 Figure 5. The light microscopic photographs. (a) non-treated wild-type, (b) IL-33425 treated wild-type, (c) Leptin + IL-33-treated wild-type, (d) non-treated ob/ob, (e) IL-33426 treated ob/ob, (f) Leptin + IL-33-treated ob/ob mice. PAS/Alcian blue stain. Scale bar = $427200 \mu \mathrm{m} .(\mathrm{g})$ Mucus score. Data are expressed as mean \pm standard error of the mean 428 (SEM). $\mathrm{n}=3-4$ for each group. ${ }^{*} \mathrm{p}<0.05, * * * \mathrm{p}<0.001$ vs. genotype-matched mice. 429 $\# \# \mathrm{p}<0.01$ vs. mice with an identical treatment.

430

431 Figure 6. MUC5AC level induced by leptin and IL-33 in vitro. Data are expressed as 432 mean \pm standard error of the mean (SEM). $\mathrm{n}=5-6$ for each group. ${ }^{* *} \mathrm{p}<0.01$, Leptin + 433 IL-33 vs. Leptin. * $p<0.05$, Leptin + IL-33 vs. IL-33. 
$439 \quad$ Figure. 1

a)

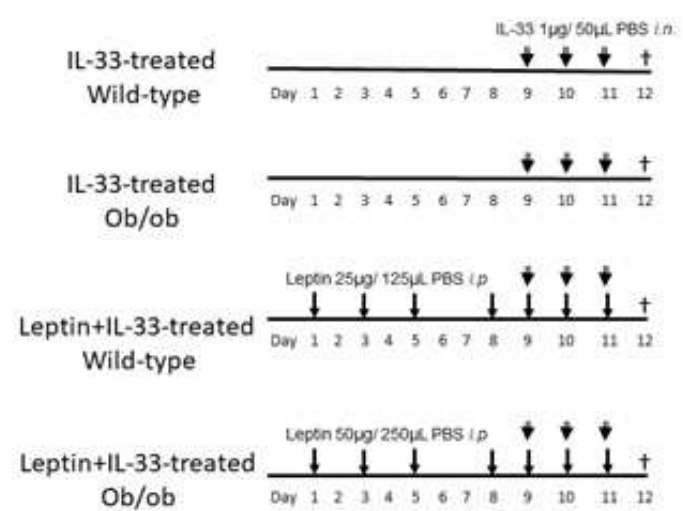

b)

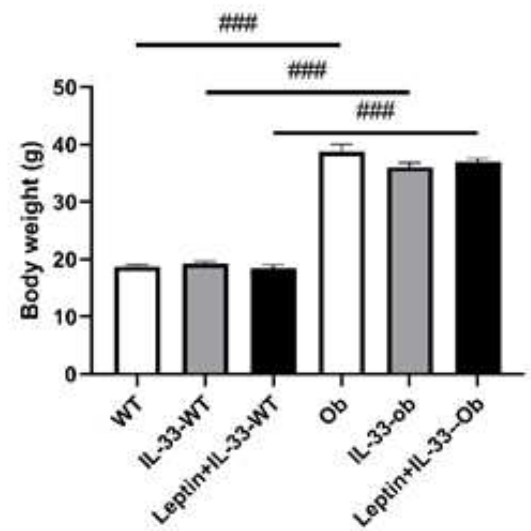


451

452

453

454 Figure. 2

a)

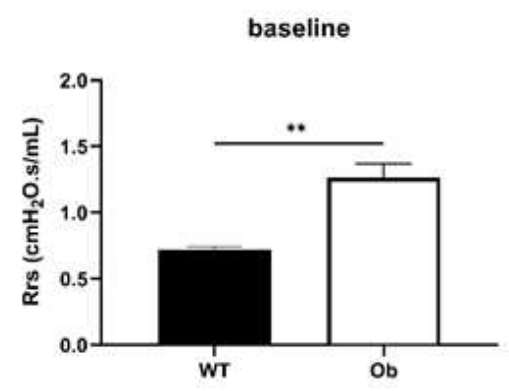

c)

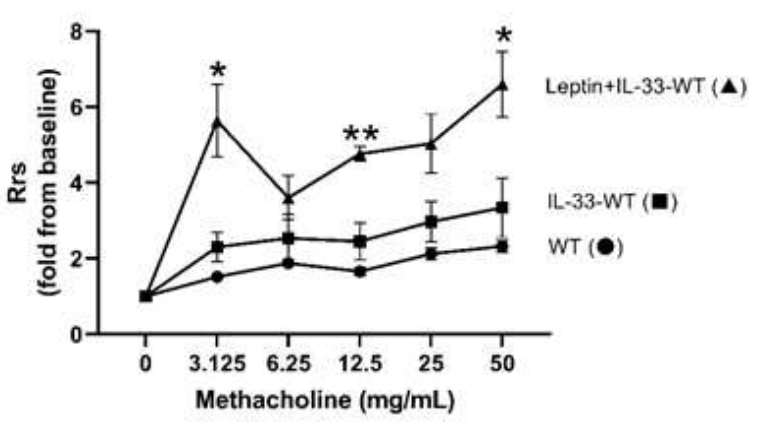

b)

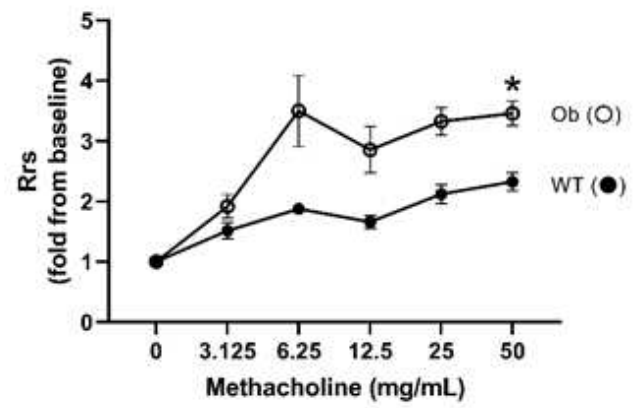

d)

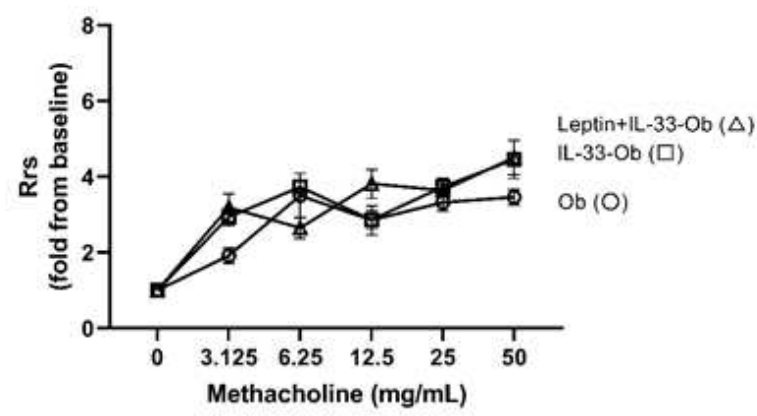

455 
465

466

467

468 Figure. 3

a)

d)
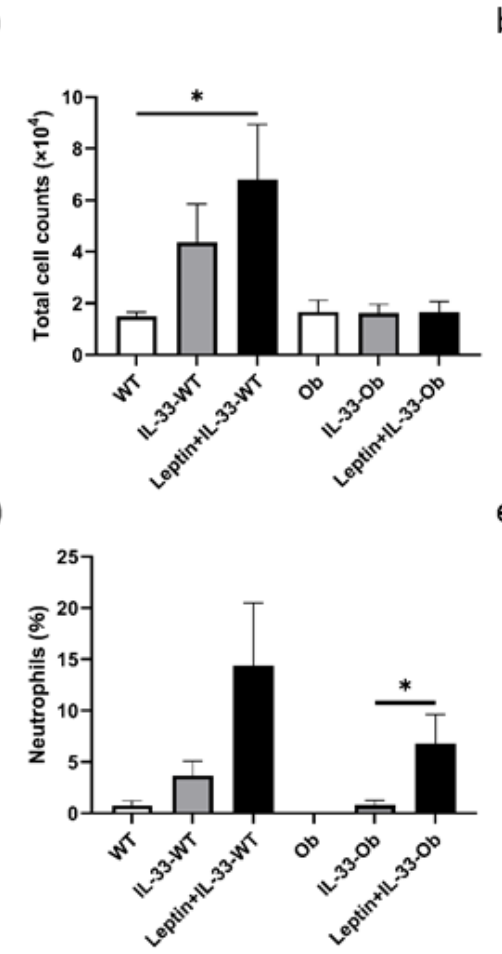

b)

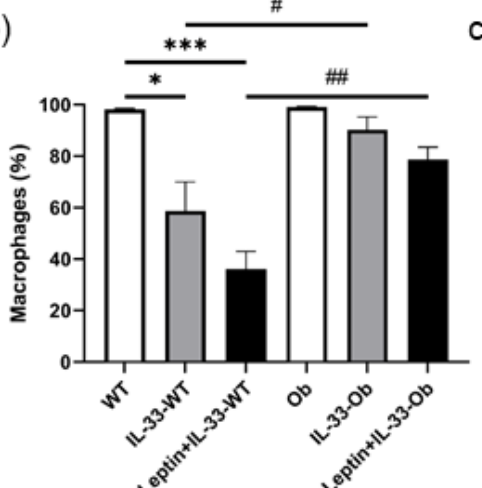

e)

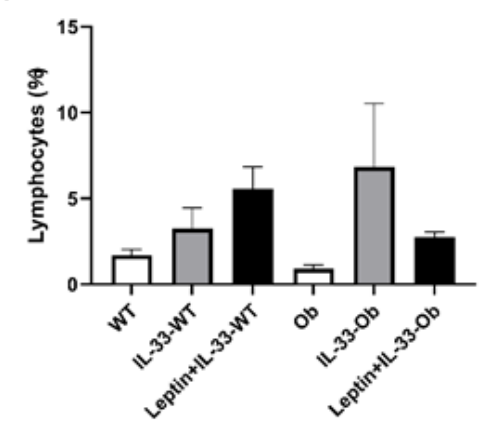

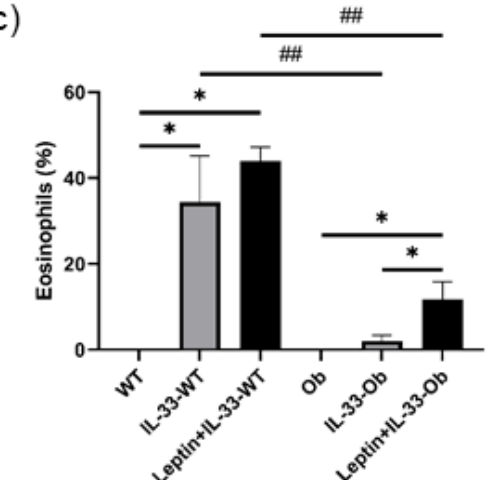

469

470

471

472

473

474

475

476

477

478 
$482 \quad$ Figure. 4

a)

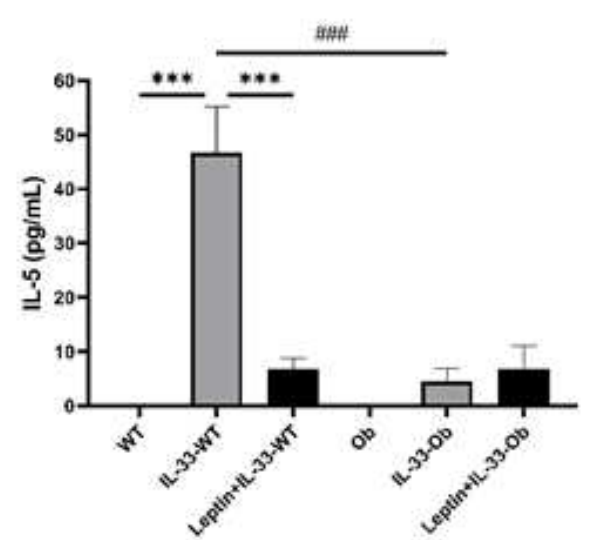

483

c)

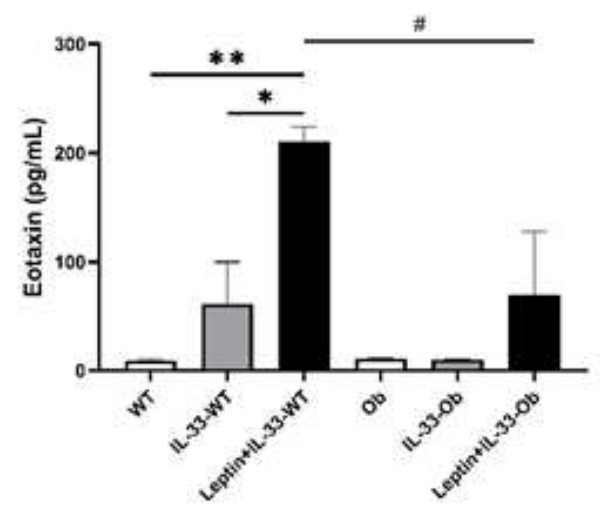

b)

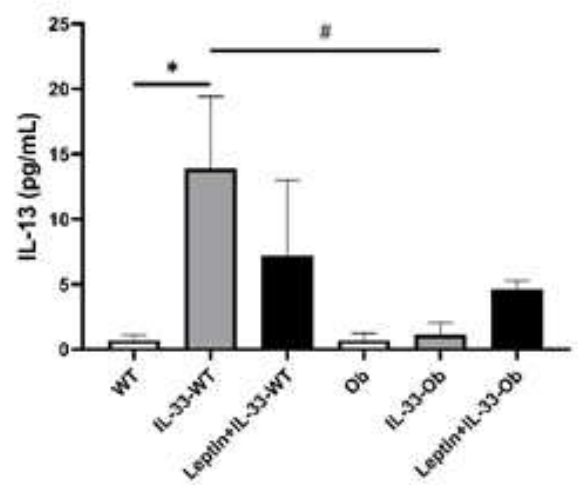

d)

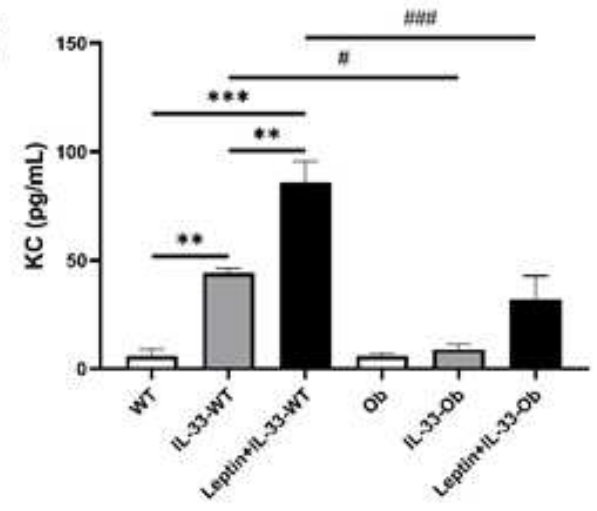

484

485

486

487

488

489

490 
491

492

493

494 Figure. 5
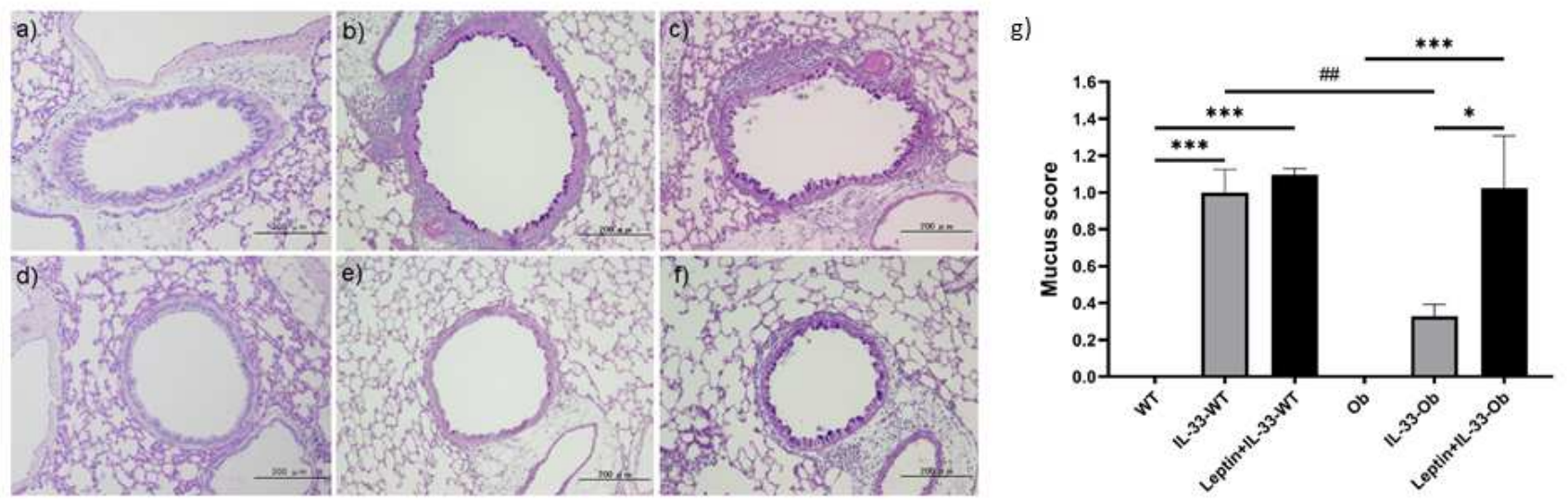

495

496

497

498

499

500

501

502

503

504

505

506 
507

508

509

510 Figure. 6

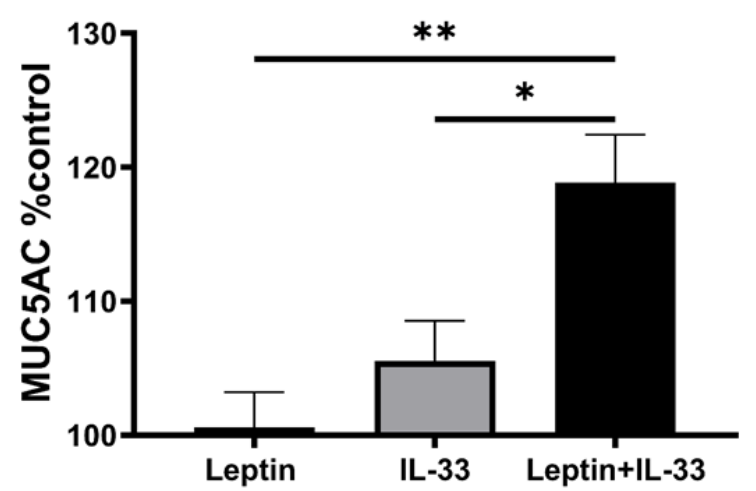

511 
Figures

a)

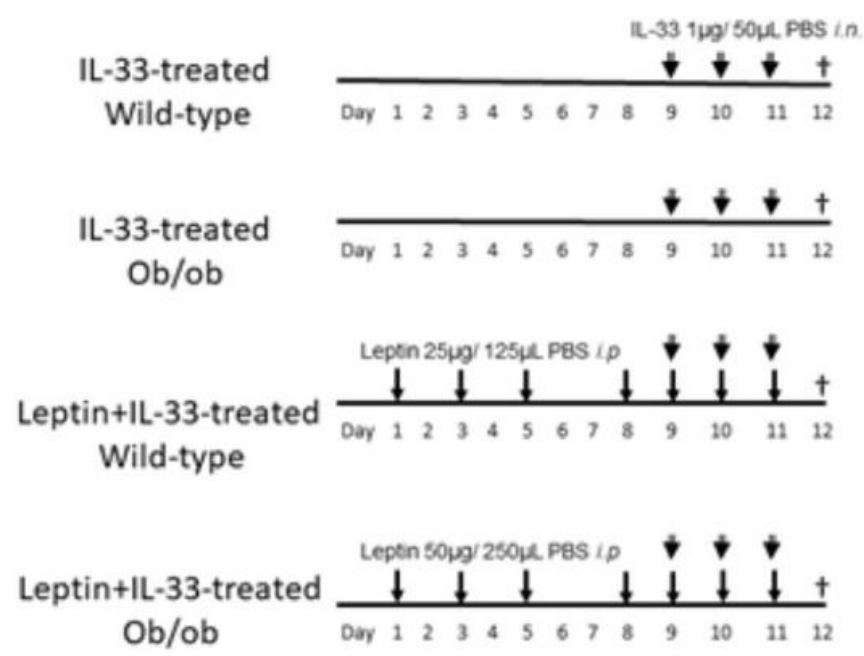

b)

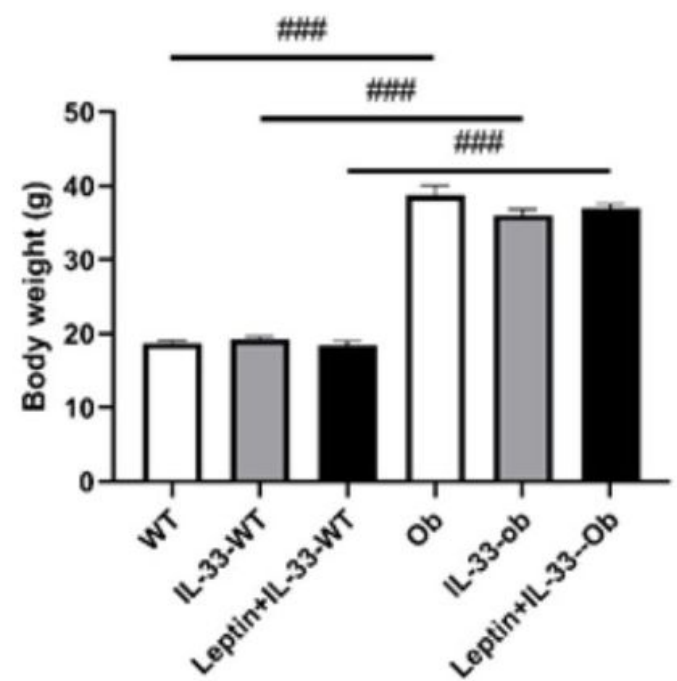

\section{Figure 1}

(a) Experimental protocol. In leptin-treated groups, leptin $(25 \mu \mathrm{g} / 125 \mu \mathrm{L}$ phosphate-buffered saline (PBS) for wild-type, $50 \mu \mathrm{g} / 250 \mu \mathrm{L}$ PBS for ob/ob) were injected intraperitoneally on days $1,3,5$, and 8-11. In IL33-treated groups, IL-33 ( $1 \mu \mathrm{g} / 50 \mu \mathrm{L}$ PBS) was instilled intranasally on days $9-11$. On day 12 , airway responsiveness, BALF, and lung sections were assessed. (b) Body weight. Data are expressed as mean \pm standard error of the mean (SEM). $n=4-6$ for each group. 咽 $p<0.001$ vs. mice with an identical treatment. 
a)

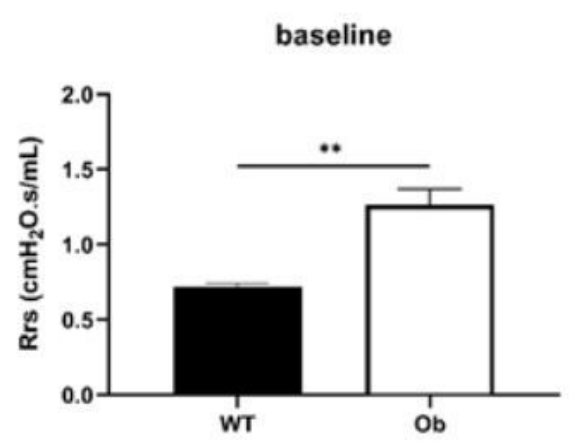

c)

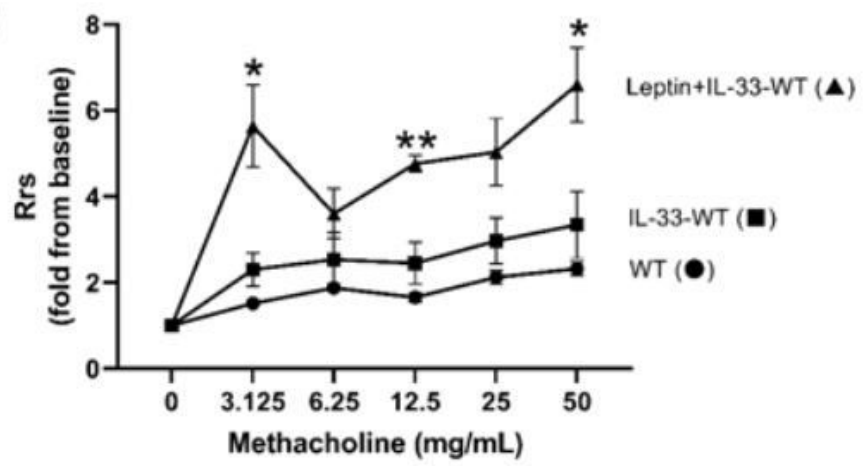

b)

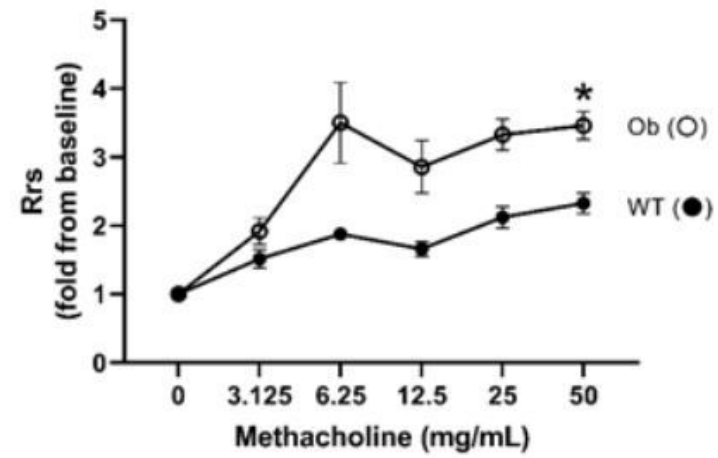

d)

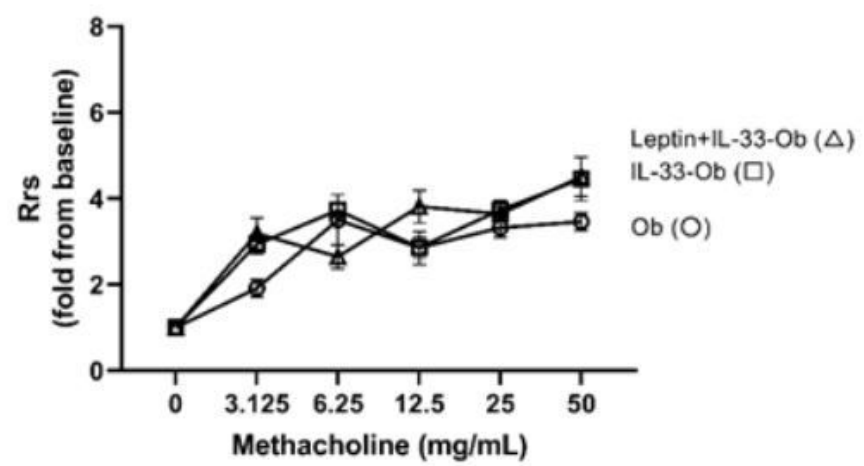

\section{Figure 2}

Airway responsiveness to methacholine. (a) Baseline resistance of the respiratory system (Rrs) in wildtype and ob/ob mice. Airway responsiveness in (b) non-treated wild-type and ob/ob mice, (c) non-treated, IL-33-treated, Leptin + IL-33- treated wild-type mice, and (d) non-treated, IL-33-treated, Leptin + IL-33treated ob/ob mice. Data are expressed as mean \pm standard error of the mean (SEM). $n=4-5$ for each group. (a) ** $p<0.01$, (b-d) Rrs is shown as fold change from baseline. Closed circle: non-treated wildtype mice. Open circle: non-treated ob/ob mice. Closed square: IL-33- treated wild-type mice. Open square: IL-33-treated ob/ob mice. Closed triangle: Leptin + IL-33-treated wild-type mice. Open triangle: Leptin + IL33-treated ob/ob mice. * $p<0.05$, ** $p<0.01$ vs. non-treated wild-type mice. 
a)

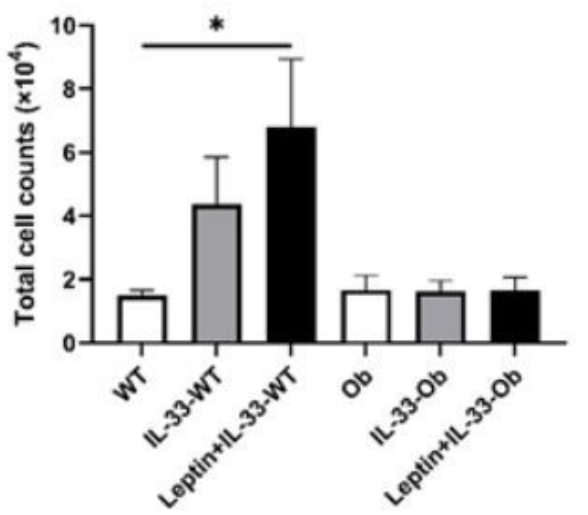

d)

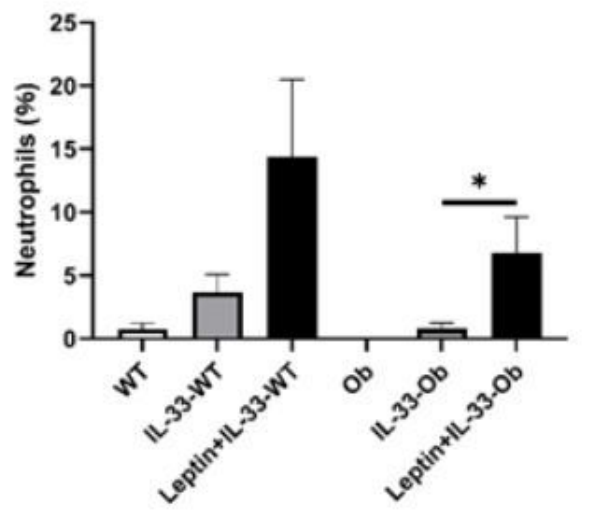

b)

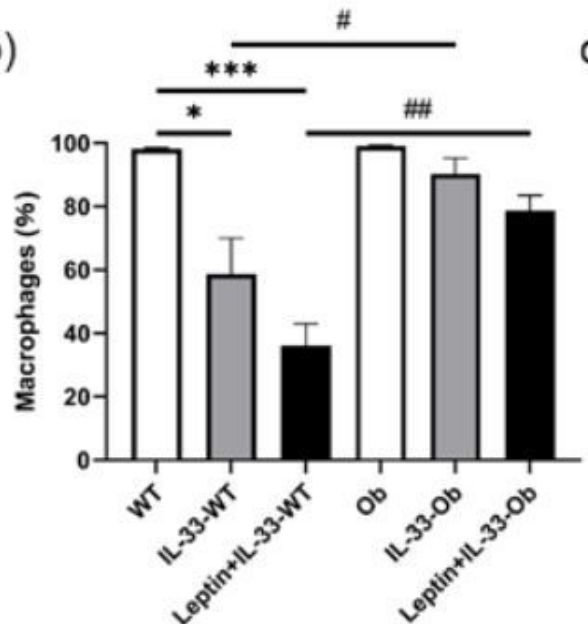

e)

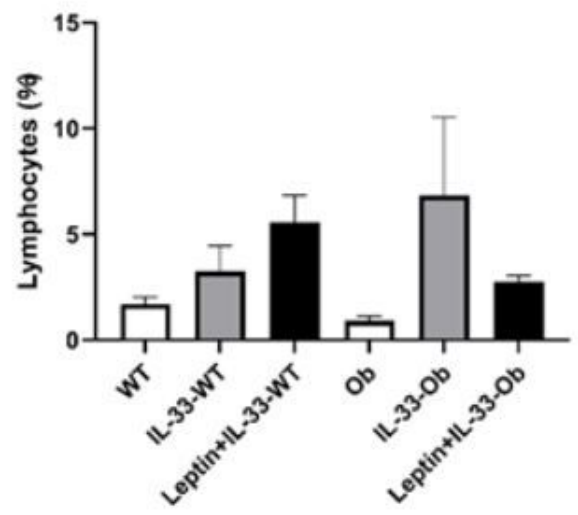

c)

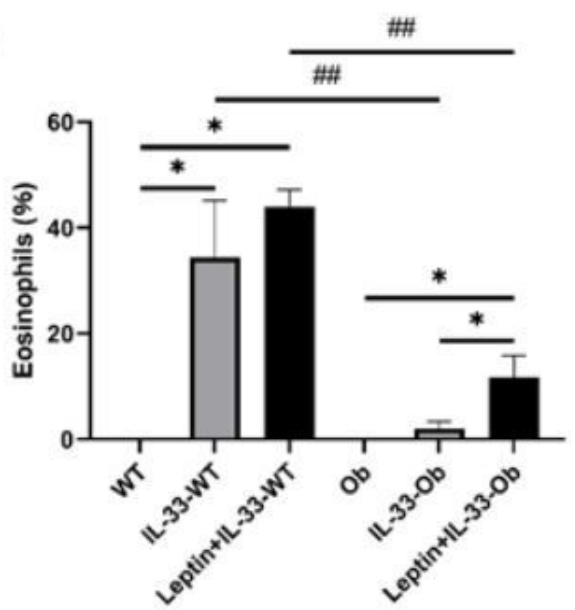

Figure 3

The cell differentials of bronchoalveolar lavage fluid. (a) Total cells, (b) \% macrophages, (c) \% eosinophils, (d) \% neutrophils, and (e) \% lymphocytes. Data are expressed as mean \pm standard error of the mean (SEM). n $414=6-9$ for each group. * $p<0.05,{ }^{\star *} p<0.01$, *** $p<0.001$ vs. genotype-matched

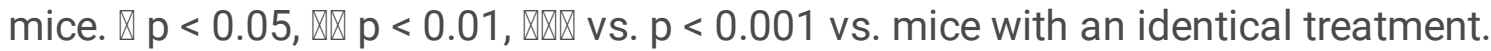


a)

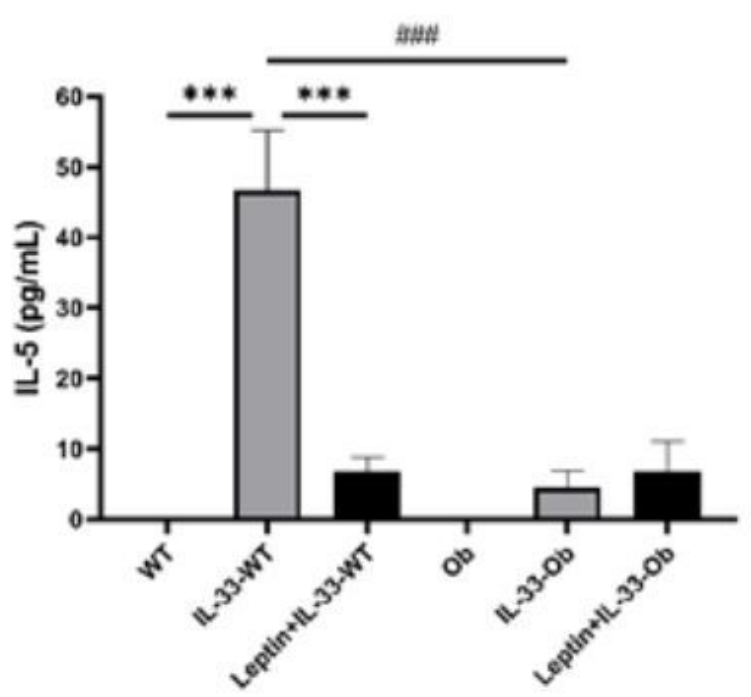

c)

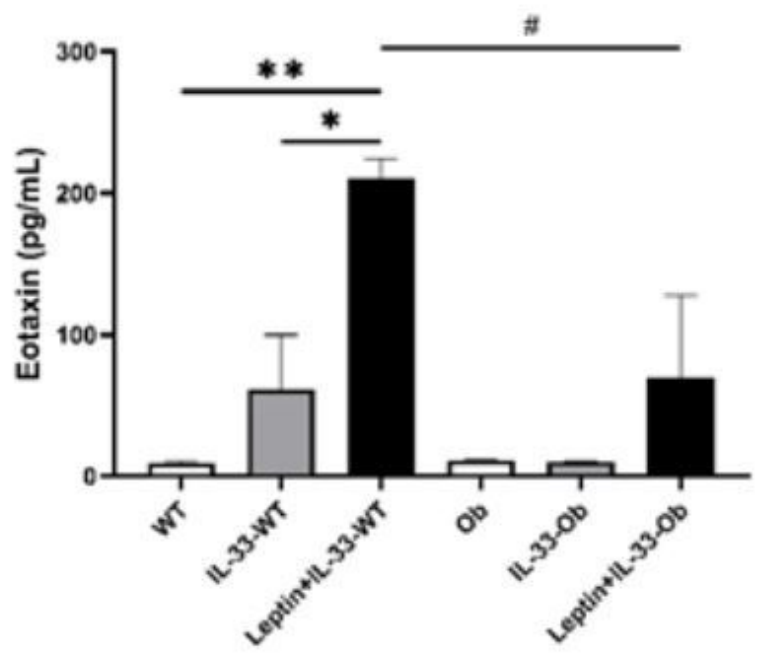

b)

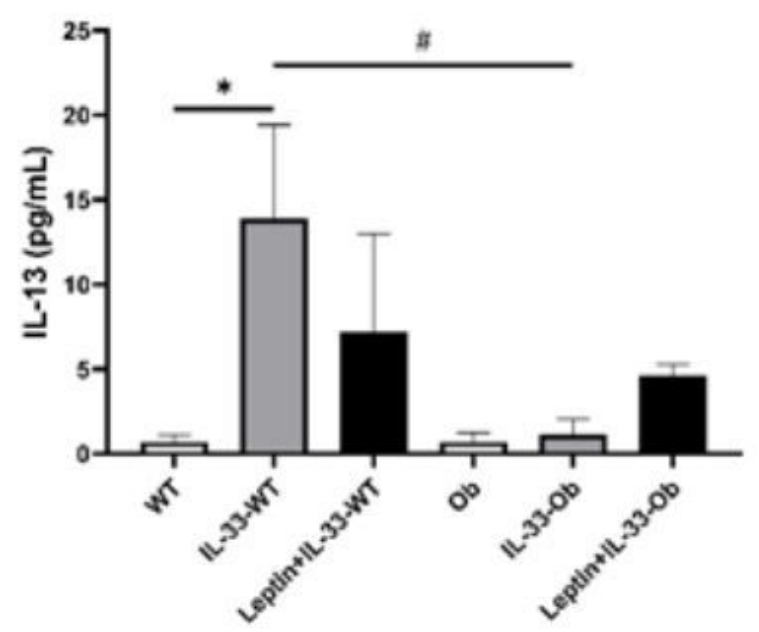

d)

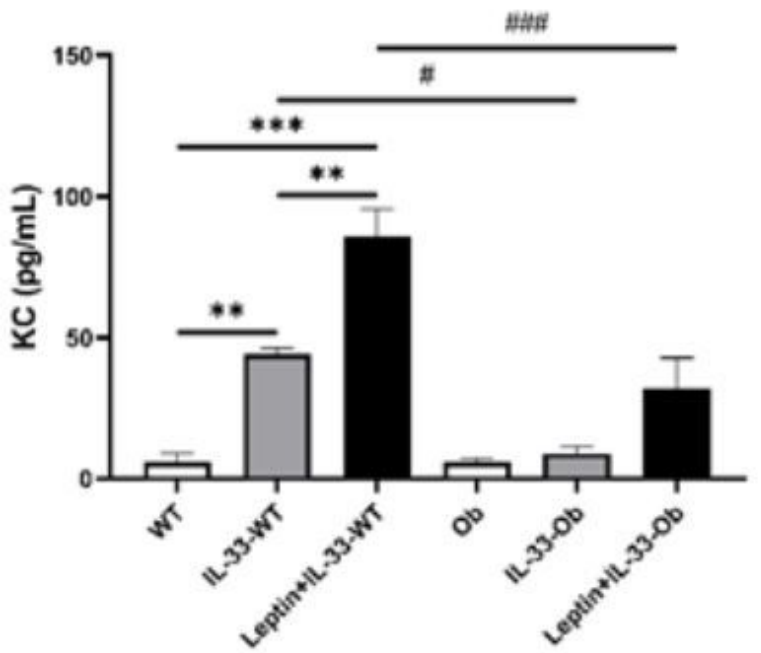

Figure 4

The cytokine and chemokine analysis in bronchoalveolar lavage fluid. (a) IL- 5, (b) IL-13, (c) Eotaxin, (d) KC. Data are expressed as mean \pm standard error of the mean (SEM). $n=6-9$ for each group. ${ }^{*} p<0.05$, **

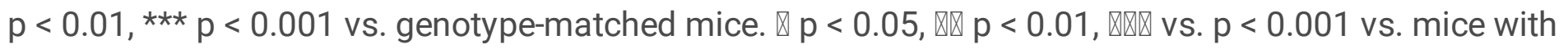
an identical treatment. 

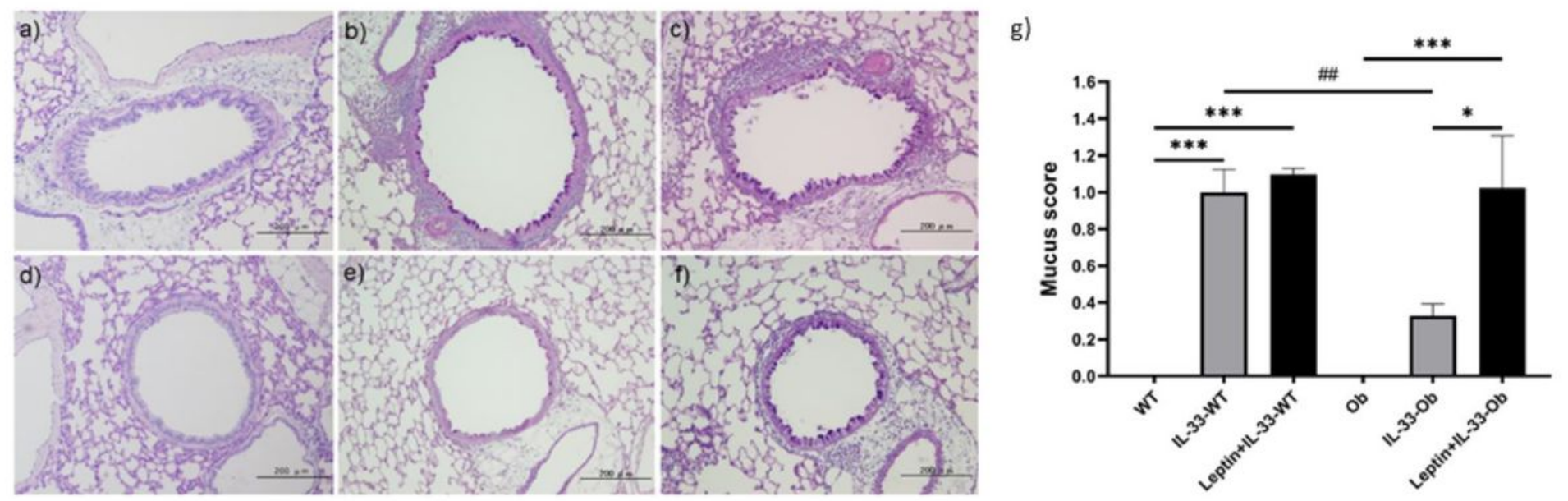

Figure 5

The light microscopic photographs. (a) non-treated wild-type, (b) IL-33- treated wild-type, (c) Leptin + IL33-treated wild-type, (d) non-treated ob/ob, (e) IL-33- treated ob/ob, (f) Leptin + IL-33-treated ob/ob mice. PAS/Alcian blue stain. Scale bar $=200 \mu \mathrm{m}$. (g) Mucus score. Data are expressed as mean \pm standard error of the mean (SEM). $n=3-4$ for each group. ${ }^{*} p<0.05,{ }^{* \star *} p<0.001$ vs. genotype-matched mice. . $\mathrm{Q} \mathrm{p}$ $<0.01$ vs. mice with an identical treatment.

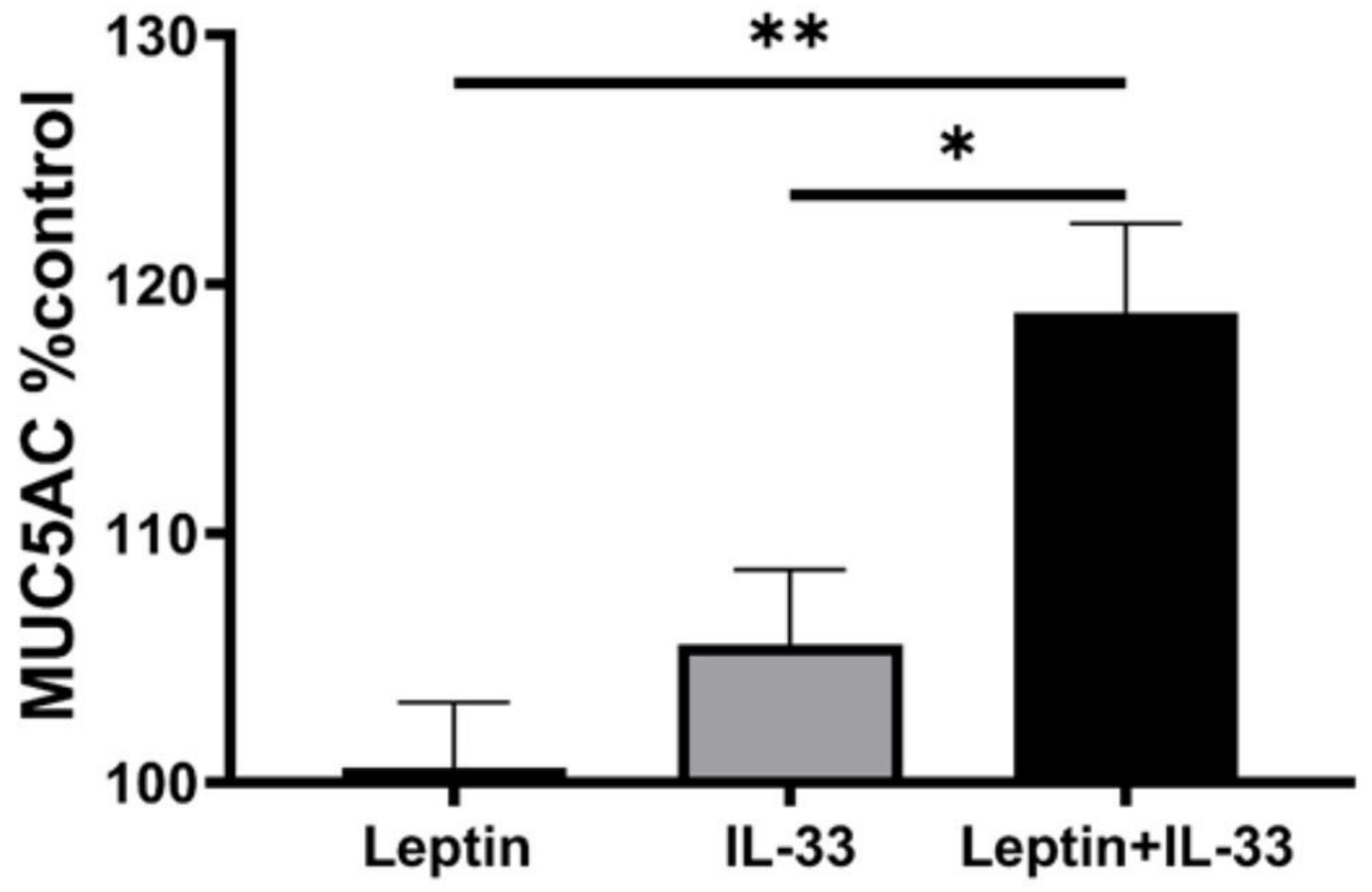


Figure 6

MUC5AC level induced by leptin and IL-33 in vitro. Data are expressed as mean \pm standard error of the mean (SEM). $n=5-6$ for each group. ${ }^{* \star} p<0.01$, Leptin + IL-33 vs. Leptin. ${ }^{*} p<0.05$, Leptin + IL-33 vs. IL33. 